\title{
KURIKULUM PRAKTIK PROFESI LAPANGAN (PPL) JURUSAN TARBIYAH STAIN KUDUS
}

\author{
Kisbiyanto
}

Dosen Jurusan Tarbiyah STAIN Kudus

\begin{abstract}
PPL is important for improving student skills. Therefore, curriculum of PPL must be sistematically organized. This research explained about (1) design and content of curriculum of PPL, (2) implementation and evaluation of PPL in State Islamic College of Kudus. This research were designed in the qualitative approach. Data were gathered by using observation and document. The validity and reliability were verified by credibility, transferability, dependability, and confirmability tests. The data were analyzed by using descriptive model. The result of research (1) the design and content of PPL for students in madrasah/islamic school with special approach in pragmatic or competence, and consist of both of teaching and school administration, (2) implementation and evaluation of PPL with higher standard for passing (70 / $3,49)$.
\end{abstract}

Keywords: PPL, Curriculum

\section{A. Pendahuluan}

\section{Latar Belakang Masalah}

Pendidikan guru di Indonesia semakin mendapatkan perhatian serius, seiring dengan tuntutan terhadap profesi guru yang harus memenuhi kriteria sebagai sarjana dan mempunyai kompetensi khusus di bidang keguruan. Undang-Undang Republik Indonesia Nomor 14 Tahun 2005 tentang Guru dan Dosen mengamanatkan bahwa guru adalah seorang yang mempunyai kualifikasi sarjana, atau setaranya. Guru adalah sarjana yang mempunyai kompetensi pedagogik, kompetensi 
kepribadian, kompetensi profesional, dan kompetensi sosial. Ketentuan formal guru di Indonesia itu sangat jelas dan merupakan bagian dari strategi nasional untuk memastikan bahwa guru-guru di Indonesia itu mempunyai kriteria yang jelas sebagai guru bermutu, layak untuk mendidik dan mengajar, serta sepantasnya mendapat kesejahteraan yang memadai dari kompensasi kerja profesionalnya.

Visi pendidikan suatu bangsa tidaklah sama. Visi pendidikan Indonesia dituangkan dalam Undang-Undang Nomor 20 Tahun 2003 tentang Sistem Pendidikan Nasional. Pendidikan nasional berfungsi mengembangkan kemampuan dan membentuk watak serta peradaban bangsa yang bermartabat dalam rangka mencerdaskan kehidupan bangsa, bertujuan untuk berkembangnya potensi peserta didik agar menjadi manusia yang beriman dan bertakwa kepada Tuhan Yang Maha Esa, berakhlak mulia, sehat, berilmu, cakap, kreatif, mandiri dan menjadi warga negara yang demokratis serta bertanggung jawab. Rumusan pendidikan dan tujuan yang divisikan oleh bangsa Indonesia benarbenar mencerminkan dasar negara dan Pancasila, yaitu berketuhanan yang maha esa, sehingga kata beriman dan bertakwa menjadi kata kunci pertama.

Sebelumnya, para pakar agak ragu-ragu untuk mengatakan bahwa guru itu suatu profesi. Namun, sistem perundangan dan peraturan lainnya sudah jelas mengatur tentang kualifikasi pendidikan, kriteria, kompetensi, standar kinerja, dan standar pendapatan guru sehingga mereka tidak ada lagi kesulitan untuk menyebut guru sebagai suatu profesi. Selayaknya profesi pada umumnya, tidak semua orang bisa menjadi guru kecuali yang memenuhi syarat, dan bagi orang yang berprofesi itu mempunyai jaminan sosial misalnya gaji atau honor yang cukup layak untuk kehidupannya.

Perguruan tinggi mempunyai strategi khusus dalam kurikulum terutama untuk mengatasi masalah relevansi dengan perkembangan dan kebutuhan. Relevansi dimaksud misalnya tentang praktik profesi lapangan (PPL) yang merupakan mata kuliah utama dengan pelaksanaan yang langsung di sekolah/madrasah. Kurikulum pada Jurusan Tarbiyah sebagai bagian dari rumpun ilmu keIslaman, mempunyai dua aspek teoritik dan praktik dalam keilmuannya. Ilmu pendidikan islam merupakan ilmu teoritik sekaligus ilmu praktik. Karenanya, 
pembelajaran agama Islam harus mendapat perhatian khusus pada aspek teoritik maupun praktiknya. Kurikulum teoritik tentulah menjadi bahan wajib. Kurikulum praktik juga menjadi penting, misalnya praktik ibadah, praktik mengajar, dan semacamnya.

Islamic studies di Indonesia mempunyai keunikan-keunikan dalam membagi pembidangan ilmu. Ada keilmuan rumpun ushuluddin, keilmuan rumpun dakwah, keilmuan rumpun syari'ah, keilmuan rumpun tarbiyah, dan keilmuan rumpun adab, serta baru-baru ini ada keilmuan rumpun ekonomi dan bisnis Islam. Keilmuan rumpun tarbiyah di bagi menjadi beberapa bagian, yaitu pendidikan agama Islam (PAI), pendidikan bahasa Arab (PBA), pendidikan guru madrasah ibtidaiyah (PGMI), pendidikan guru raudlatul athfal (PGRA), kependidikan Islam/ manajemen pendidikan Islam (KI/MPI), dan tadris matematika dan ilmu pengetahuan alam (T-MIPA) meliputi matematika, fisika, biologi, kimia. Program studi di keilmuan rumpun tarbiyah dengan pembagian seperti itu tentu sangat berbeda dengan cara kampus-kampus di negera-negara lain yang mengembangkan keilmuan tarbiyah.

Keilmuan rumpun tarbiyah di Indonesia juga akan dikembangkan terus seiring dengan perkembangan keilmuan, kebutuhan dan tuntutan masyarakat. Asal muasalnya, tarbiyah hanya membidangi pendidikan agama Islam (PAI). Pengembangan tarbiyah memunculkan bidang pendidikan bahasa Arab (PBA), kemudian disusul bidang-bidang lain hingga terdapat KI/MPI, PGRA, PGMI, Tadris. Sekarang ini, bidang tadris masih terbatas pada MIPA, dan pada waktu-waktu yang akan datang akan terus dikembangkan banyak bidang yang pendidik calon-calon guru untuk semua jenis ilmu dan mata pelajaran. Artinya, pembidangan keilmuan itu menyesuaikan perkembangan zaman dan kebutuhan masyarakat.

PPL sebagai bagian utama praktikum di Jurusan Tarbiyah juga mempunyai kepentingannya sendiri untuk dievaluasi dan dikembangkan agar desain, ancangan, pelaksanaan, serta hasilnya bisa disesuaikan dengan perkembangan dan kebutuhan sosial masyarakat yang menggunakan jasa pendidik. PPL sebagai mata kuliah praktik lapangan di sekolah maupun madrasah juga membutuhkan penajaman visi maupun materi agar sesuai dengan harapan.

Berbagai upaya untuk pengembangan kurikulum di perguruan 
tinggi tersebut sangat menarik karena merupakan bidang penting dalam perkembangan pendidikan dewasa ini. Berbagai alasan dan latar belakang di atas, menjadikan penelitian ini terfokus pada tema kajian yang berjudul Kurikulum PPL Jurusan Tarbiyah STAIN Kudus.

\section{Fokus Penelitian}

Penelitian ini adalah tentang kurikulum praktik pada pembelajaran agama Islam, yang secara rinci difokuskan pada hal-hal sebagai berikut :

a. Bagaimana desain dan isi kurikulum yang berorientasi pada pelaksanaan praktik profesi lapangan (PPL) di Jurusan Tarbiyah STAIN Kudus?

b. Bagaimana pelaksanaan dan evaluasi praktik profesi lapangan (PPL) di Jurusan Tarbiyah STAIN Kudus?

\section{Batasan Masalah}

Banyak masalah dalam hal berkaitan dengan kurikulum bermuatan praktik pada perguruan tinggi agama Islam, namun dalam penelitian ini dibatasi cakupan pembahasannya pada aspek : (1) kebijakan desain dan isi kurikulum yang berorientasi pada pelaksanaan praktik profesi lapangan (PPL) di Jurusan Tarbiyah STAIN Kudus, (2) pelaksanaan dan evaluasi praktik profesi lapangan (PPL) di Jurusan Tarbiyah STAIN Kudus.

\section{Tujuan Penelitian}

Penelitian ini lakukan dengan tujuan sebagai berikut :

a. Menjelaskan desain dan isi kurikulum yang berorientasi pada pelaksanaan praktik profesi lapangan (PPL) di Jurusan Tarbiyah STAIN Kudus.

b. Menjelaskan pelaksanaan dan evaluasi praktik profesi lapangan (PPL) di Jurusan Tarbiyah STAIN Kudus.

\section{Manfaat Penelitian}

Penelitian ini diharapkan dapat memberikan manfaat, baik secara teoritis maupun secara praktis sebagai berikut :

a. Manfaat teoritis penelitian ini adalah kajian tentang perancangan dan 
pengembangan kurikulum praktis, yaitu kurikulum yang mendukung pelaksanaan praktik profesi lapangan bagi mahasiswa Tarbiyah.

b. Manfaat praktis penelitian ini adalah memberikan informasi dan masukan kepada para pengelola dan pendidik, serta perguruan tinggi yang menyelenggarakan pendidikan tinggi, baik untuk dosen, mahasiswa, dan para ahli dan praktisi pendidikan tinggi khususnya, dan semua pendidikan secara luas.

\section{B. Kajian Pustaka}

\section{Kurikulum dan Pengembangannya}

\subsubsection{Kurikulum Perguruan Tinggi}

Pendidikan tinggi di Indonesia melaksanakan proses pembelajaran dengan mengacu pada kurikulum nasional. Di samping itu, lembaga pendidikan juga menerapkan kurikulum muatan lokal yang ditentukan oleh masing-masing satuan lembaga pendidikan. Kedua macam kurikulum itu merupakan keharusan bagi setiap lembaga pendidikan untuk menerapkannya. Menurut UU RI No. 20 Tahun 2003, kurikulum pendidikan wajib memuat : pendidikan agama, pendidikan kewarganegaraan, bahasa, dan ilmu-ilmu dasar dan ilmu-ilmu terapan yang mendukung tujuan pendidikan masing-masing fakultas, jurusan, dan program studi. Sedangkan menurut UU RI No. 12 Tahun 2012, kurikulum pendidikan tinggi wajib memuat agama, pancasila, kewarganegaraan, dan bahasa Indonesia.

Pengembangan kurikulum menurut Hendyat Soetopo dan Wasty Soemanto (1986:41) adalah kegiatan menghasilkan kurikulum baru melalui langkah-langkah penyusunan, pelaksanaan dan penyempurnaan kurikulum atas dasar hasil penilaian yang dilakukan selama kegiatan pengembangan tersebut. Sedang pengembangan kurikulum dalam rumusan Soetopo (1986:45) didefinisikan sebagai the proces of analizing and refining goals, aims and objectives, together with the translation of these into the content of course by formal or informal methods. Kegiatan pengembangan kurikulum meliputi penyusunan kurikulum, pelaksanaannya di dalam proses belajar mengajar dan penyempurnaan terhadap komponen-komponen tertentu atas dasar hasil penilaian.

Menurut Nasution (1993:1-2), pengembangan kurikulum 
didasarkan atas asas-asas tertentu, yaitu : (1) asas filosofis yang pada hakekatnya menentukan tujuan umum pendidikan, (2) asas sosiologis yang memberikan dasar untuk menentukan apa yang akan dipelajari sesuai dengan kebutuhan masyarakat, budaya dan perkembangan ilmu pengetahuan dan teknologi, (3) asas organisatoris yang memberikan dasar-dasar dalam bentuk bagaimana bahan pelajaran disusun dan bagaimana luas dan urutannya, dan (4) asas psikologis yang memberikan prinsip-prinsip tentang perkembangan manusia dalam berbagai aspek serta cara belajar agar bahan yang disediakan dapat dicerna dan dikuasai peserta didik sesuai dengan taraf perkembangannya.

Hendyat Soetopo dan Wasty Soemanto (1986 : 46) menerangkan bahwa landasan pengembagan kurikulum dapat menjadi "titik tolak" sekaligus menjadi "titik sampai". Titik tolak berarti pengembangan kurikulum dapat didorong oleh pembaharuan tertentu seperti penemuan teori belajar yang baru dan perubahan tuntutan masyarakat. Titik sampai berarti kurikulum harus dikembangkan sedemikian rupa sehingga dapat merealisasikan perkembangan tertentu, seperti impak kemajuan ilmu pengetahuan dan teknologi, tuntutan-tuntutan sejarah masa lalu, perbedaan latar belakang peserta didik, nilai-nilai filsafat suatu masyarakat dan tuntutan-tuntutan kultur tertentu.

Perencanaan menurut St. Vembriarto (1993:28) dalam bukunya Pengantar Perencanaan Pendidikan adalah penggunaan analisis yang bersifat rasional dan sistematis terhadap proses pengembangan pendidikan yang bertujuan untuk menjadikan pendidikan lebih efektif dan efisien dalam menanggapi kebutuhan dan tujuan peserta didik dan masyarakat. Ada empat persoalan penting yang dibahas dalam perencanaan, yaitu (1) tujuan apa yang dicapai dengan perencanaan itu, (2) status sistem pendidikan yang ada dan bagaimana keadaannya sekarang, (3) kemungkinan-kemungkinan pilihan apa yang ditempuh untuk mencapai tujuan, dan (4) strategi yang terbaik untuk mencapai tujuan. Jadi perencanaan dalam pendidikan adalah sebagai fungsi manajemen pendidikan. Fungsi perencanaan tersebut adalah untuk menentukan keadaan yang sebaik-baiknya dari hubungan-hubungan sumber daya internal dan eksternal dalam suatu sistem pendidikan dengan keadaaan yang dinamis serta cara yang efisien dan efektif untuk mencapai tujuan yang diinginkan. 
Salah satu sumber daya yang harus direncanakan adalah "materi pendidikan" atau kurikulum. Sumber daya "kurikulum" ini membutuhkan perencanaan yang tepat dan strategis. Hasil perencanaan kurikulum yang baik menentukan keberhasilan dalam pencapaian tujuan pendidikan. Dalam konteks perkembangan, kurikulum harus selalu dikembangkan. Fungsi perencanaan kurikulum dan pengembangnnya itu dimaksudkan untuk pengelolaan pendidikan agar tidak mengalami ketertinggalan. Soetopo (1986:40-41) mengemukakan tiga faktor umum yang mendorong pengembangan kurikulum, yaitu (1) perubahan yang diinginkan masyarakat sehingga mereka merencanakan adanya perubahan yang cukup penting di dalam kurikulum dan sistem pendidikan, (2) perkembangan ilmu pengetahuan dan teknologi yang pesat, dan (3) pertambahan pesat penduduk dunia. Menurut Nasution (1993:159) dalam bukunya Pengembangan Kurikulum, proses pengembangan kurikulum dijalankan karena (1) hasil penelitian dan pengembangan, (2) interaksi sosial, dan (3) metode pemecahan masalah.

Menurut Soetopo (1986:48), prinsip-prinsip dasar pengembangan kurikulum meliputi : (1) prinsip relevansi, yang meliputi relevansi dengan lingkungan, perkembangan masa dan tuntutan dunia kerja, (2) prinsip efektifitas yang meliputi efektifitas mengajar pendidik dan efektifitas belajar peserta didik, (3) prinsip efisiensi dalam penggunaan sumber daya pendidikan. Prinsip-prinsip pengembangan kurikulum menurut Subandijah (1993:48) adalah : (1) prinsip relevansi, (2) prinsip efektifitas dan efisiensi, (3) prinsip kesinambungan, (4) prinsip fleksibilitas, (5) prinsip berorientasi pada tujuan, (6) prinsip pendidikan seumur hidup, dan (6) prinsip kesesuaian dengan model pengembangan kurikulum.

Pendekatan dalam pengembangan kurikulum diorientasikan pada (1) tujuan pendidikan dan (2) bahan pelajaran. Subandijah (1993:55) mengemukakan tiga pendekatan dengan pola organisasi bahan sebagai berikut : (1) pendekatan dengan pola subject matter curriculum, yaitu pendekatan yang menekankan pada mata pelajaran/ mata kuliah secara terpisah-pisah, (2) pendekatan dengan pola corelated curriculum, yaitu pendekatan dengan pola pengelompokan beberapa mata kuliah yang seiring (serumpun), dan (3) pendekatan dengan pola integrated curriculum, yaitu pendekatan dengan penyatuan keseluruhan 
mata kuliah sebagai bahan ajar yang sistematik-integralistik. Langkahlangkah utama dalam perencanaan kurikulum --misalnya dengan model Tyler dalam Nasution (1993:140) - meliputi (1) menentukan tujuan pendidikan, (2) menentukan proses belajar mengajar, (3) menentukan organisasi kurikulum, dan (4) menentukan cara penilaian hasil belajar. Adapun tahap-tahap dalam pengembangan kurikulum menurut Subandijah (1993:215) adalah : (1) pengembangan kurikulum pada tingkat lembaga, (2) pengembangan kurikulum pada tingkat/setiap bidang studi, dan (3) pengembangan pengajaran di kelas. Tahap-tahap pengembangan kurikulum di perguruan tinggi dijalani secara terstruktur, sepanjang masa dari tahun ke tahun selama satu periode pemberlakuan kurikulum berkisar antara 4 hingga 5 tahun.

Guru bermutu juga terkait dengan kurikulum, merupakan guru ideal yang memenuhi ketentuan kualifikasi maupun kompetensikompetensi yang menunjukkan kemampuan unjuk kerja sebagai pendidik sesuai bidangnya. Guru Matematika misalnya, adalah guru yang berpendidikan kesarjanaan di bidang Matematika, menguasai kemahiran dalam bidang matematika, menguasai dasar-dasar pengajaran dan terampil dalam praktik dan pengembangannya, bisa berkolaborasi dengan orang lain di sekitarnya serta mempunyai kebribadian yang matang sebagai guru yang bertugas mendidik, membimbing, dan melatih peserta didiknya. Guru bermutu secara teoritik bisa dilihat dari dua aspek yaitu kemampuan berpikir abstrak dan komitmen. Kemampuan berpikir abstrak menunjuk pada tingkat kecerdasan guru, bahwa guru haruslah seorang yang cerdas dengan menguasai ilmu dan pengetahuan secara matang. Komitmen menunjuk pada tingkat kesetiaan dan kecintaan seorang guru dalam melaksanakan tugas profesinya sebagai pendidik. Dua kriteria guru menurut Glickman itu mengkonsepkan empat macam guru dengan derajat mutu yang berbeda, yaitu guru berhasil, guru pengkritik, guru penganut, dan guru gagal.

Guru bermutu juga bisa dilihat dari penguasaan kompetensi, yaitu kompetensi pedagogik, kompetensi kepribadian, kompetensi profesional, dan kompetensi sosial. Pembagian kompetensi seperti itu untuk mengukur mutu guru secara nasional di Indonesia, sesuai dengan sistem perundangan yang berlaku. Adapun, secara teoritik, kompetensi guru itu banyak sekali, yaitu meliputi sepuluh kompetensi yang sudah 
sejak lama menjadi acuan untuk menilai kemampuan guru. Kesepuluh kompetensi itu meliputi : menguasai bahan ajar, mengelola program belajar mengajar, mengelola kelas, menggunakan media/sumber belajar, menguasasi landasan-landasan kependidikan, mengelola interaksi belajar mengajar, menilai prestasi siswa untuk kepentingan pengajaran, mengenal fungsi dan program bimbingan dan penyuluhan di sekolah, mengenal dan menyelenggarakan administrasi sekolah, memahami prinsip-prinsip dan menafsirkan hasil penelitian pendidikan guna keperluan pengajaran. Kompetensi-kompetensi guru tersebut mempunyai indikator-indikator operasional yang menunjukkan kemampuan nyata guru dalam unjuk kerjanya. Indikator itu bersifat teknis dan menjadi tolok ukur untuk menilai kemampuan guru yang bermutu atau sebaliknya.

Kompetensi profesional, senada dengan kompetensi penguasaan bahan ajar berarti guru harus menguasai sekurangnya tiga hal yaitu ilmu pengetahuan yang menjadi disiplin keilmuannya secara luas dan mendalam, menguasai materi pengaran sesuai dengan struktur kurikulum yang belaku di sekolah, dan menguasai materi pengembangan dan perkembangan terbaru di bidang dan rumpunnya itu. Jadi, seorang guru agama di samping menguasai secara luas dan mendalam tentang berbagai ilmu agama, meliputi qur'an, hadits, akidah, akhlak, fiqih, dan sejarah dan kebudayaan Islam. Guru agama itu juga harus memahami betul materi-materi keagamaan yang luas itu, mana yang khusus menjadi kurikulum di sekolah/madrasah sesuai tingkatannya, agar fokus dan tidak meluas ke pembahasan lainnya. Guru agama juga tidak boleh ketinggalan informasi dan perkembangan terbaru tentang ilmu-ilmu agama di era kontemporer saat ini, yang berarti dia harus berwawasan luas dan mengikuti perkembangan.

Kompetensi pedagogik, senada dengan kompetensi mengelola program belajar mengajar, mengelola kelas, menggunakan media/ sumber belajar, menguasasi landasan-landasan kependidikan, mengelola interaksi belajar mengajar, menilai prestasi siswa untuk kepentingan pengajaran, mengenal dan menyelenggarakan administrasi sekolah, memahami prinsip-prinsip dan menafsirkan hasil penelitian pendidikan guna keperluan pengajaran merupakan kompetensi di bidang ketetampilan mengajar. Guru harus menguasai cara menyusun 
rencana pengajaran, langkah-langkah dalam strategi mengajar, hingga mengevaluasi hasil belajar peserta didiknya. Guru juga harus terampil memilih dan menggunakan media atau alat peraga yang tepat untuk menjadikan suatu tindak pengajaran lebih menarik dan efektif. Guru juga harus memahami dengan baik lantar belakang dan karakteristik peserta didiknya, sehingga dia akan bisa memlilih metode dan pendekatan yang tepat dalam mengajar. Guru juga harus terampil dalam administrasi pengajaran maupun administrasi pada umumnya di sekolah/madrasah supaya dia bisa tertib dan efisien serta efektif dalam menjalan profesinya. Guru juga harus berwawasan luas dalam mengakses, memahami, dan menerapkan temuan-temuan inovatif atau model-model baru yang baik untuk diterapkan di sekolahnya.

Kompetensi kepribadian, senada dengan mengenal fungsi dan program bimbingan dan penyuluhan di sekolah, yaitu bahwa guru harus benar-benar seorang yang matang secara personal, baik ucapan, sikap, dan perbuatan karena hal itu menjadi contoh nyata bagi peserta didik. Di samping itu, guru juga harus mempunyai ilmu dan strategi yang cukup untuk memberikan bimbingan kepada peserta didiknya sehingga mereka menjadi orang yang bermotivasi tinggi untuk belajar dan berhasil, serta menjadi orang yang mempunyai akhlak mulia.

Kompetensi sosial, berarti bahwa guru mampu berinteraksi dengan berbagai pihak, baik dengan peserta didik, dengan pimpinan dan teman sejawatnya, dengan pimpinan dan pejabat di lingkungan kerja lebih luas, misalnya kantor dinas pendidikan/atau kantor kementerian agama, dan juga berinteraksi dengan orang tua/wali siswa serta berinteraksi dengan masyarakat sekitar. Interaksi dengan berbagai pihak itu dijalin dengan sebaik-baiknya karena akan berpengaruh kepada kinerja pribadinya sebagai guru, dan lebih-lebih akan berpengaruh pada lembaga pendidikan tempat kerjanya. Guru merupakan insan berprofesi yang jelas, baik pekerjaan maupun konsekwensinya dalam melaksanakan tugas profetiknya. Banyak guru yang cerdas dan terampil dengan kehidupan yang layak dan berkecukupan. Guru tidak hanya menjadi pekerja, tetapi juga menjadi inspirator bagi bangsanya, dan selayaknya mereka berkehidupan yang pantas sebagai guru suatu bangsa. Guru yang melaksanakan tugas dengan baik itu, juga mempunyai karir keguruan yang menunjukkan keberhasilan dan prestasi. 
Guru bisa berkarir di sekolah/madrasah menjadi pimpinan di sekolah/madrasah, misalnya menjadi kepala sekolah, wakil kepala sekolah, dan pembina keorganisasi siswa. Guru juga bisa berkarir di bidang pendidikan di luar lingkungan sekolah/madrasah, misalnya menjadi pengawasa sekolah, menjadi pejabat di dinas pendidikan yang mengurusi tentang pendidikan, pejabat di kantor kementerian agama yang mengurusi pendidikan, dan sebagainya. Tentu saja, karirkarir tersebut mensyarakatkan kemampuannya yang cakap dalam melaksanakan tugas sebagai guru selama ini. Lebih luas lagi, guru juga mempunyai karir sebagai pimpinan lebih tinggi lagi, misalnya sebagai pejabat di lingkungan kabupaten/atau provinsi, maupun pemerintahan pusat. Guru juga bisa menjadi pimpinan di yayasan/ atau badan hukum tertentu di lingkungan pendidikan ataupun lainnya, asalkan kemampuannya dipandang mumpuni untuk menduduki jabatan tersebut. Selain itu, guru dalam melaksanakan tugasnya sebagai pendidik, pembimbing, dan pelatih di sekolah juga bisa mempunyai karir pendamping lainnya, misalnya menjadi trainer atau pelatih bagi guruguru lain, menjadi motivator, menjadi penulis buku, menjadi peneliti, dan semacamnya. Karir seperti itu tidak memerlukan peluang khusus untuk menduduki suatu jabatan, tetapi memerlukan ilmu pengetahuan, pengalaman, serta ketekunan yang tinggi.

\section{Metode Penelitian}

\section{Pendekatan Penelitian}

McMillan (2001:29) menjelaskan bahwa penelitian dengan pendekatan kualitatif mempunyai beberapa model, yaitu etnografi, fenomenologi, studi kasus, grounded theory, critical studies, concept analysis dan historical analysis. Model yang digunakan dalam penelitian ini adalah pendekatan kualitatif adalah bukan dimaksudkan untuk menguji suatu teori, tetapi untuk mengungkapkan fenomena dan realitas melalui data-data secara deskriptif. Data-data spesifik dicari maknanya untuk membuat kesimpulan yang general dari makna-makna yang diperoleh dari data-data tersebut. Penelitian ini dirancang untuk menjelaskan tentang materi perkuliahan yang berorientasi pada praktik mengajar atau PPL pada Jurusan Tarbiyah di STAIN Kudus. 


\section{Subyek dan Sumber Penelitian}

Sumber informasi utama dalam penelitian ini adalah dokumentasi di STAIN Kudus. Untuk memperoleh data yang absah, sumber informasi ditentukan secara purposif, yaitu para dokumen yang dianggap bisa memberikan data yang akurat, maka dituju sebagai sumber yang pokok. Peneliti mengklasifikasi sumber-sumber tersebut dalam pembagian bidang yang diteliti tentang kurikulum, isinya, dan evaluasi pelaksanaannya di STAIN Kudus.

\section{Lokasi dan Waktu Penelitian}

Agar diperoleh kesesuaian antara persoalan yang fokus dengan setting penelitian, sebagaimana dianjurkan oleh Moleong (1994), dilakukan penjajakan dan penilaian lapangan, dalam hal ini adalah pada Jurusan Tarbiyah STAIN Kudus.

Penelitian dengan pendekatan kualitatif tidak ditentukan batas waktu secara jelas sampai peneliti memperoleh pemahaman yang benar-benar mendalam tentang obyek yang diteliti. Namun karena pertimbangan dan keterbatasan waktu, biaya dan tenaga, maka penelitian dapat diakhiri dan dibuat laporannya jika dianggap telah mencapai data dan analisis sesuai dengan rancangan.

\section{Teknik Pengumpulan Data}

Dokumentasi dilakukan untuk mendapatkan informasi dari sumber yang berupa dokumen/arsip, foto, dan bahan statistik yang lain. Data diperoleh dari dokumentasi data-data, baik yang berupa tulisan/ dokumen resmi maupun dokumen pribadi seperti makalah, artikel, catatan dan surat-surat, misalnya buku panduan, buku laporan, buku laporan dan sebagainya. Dalam hal ini, dokumentasi utamanya adalah administrasi perkuliahan dan praktik profesi lapangan di STAIN Kudus.

\section{Keabsahan Data}

Agar data yang diperoleh, yang berujung pada kesimpulan atau verifikasi, dapat dipertanggungjawabkan secara ilmiah, maka dilakukan pemeriksaan keabsahan data. Teknikyang digunakan dalam pemeriksaan keabsahan data dalam penelitian ini, sebagaimana dikatakan Moleong (2001) meliputi : perpanjangan keikutsertaan, ketekunan pengamatan, triangulasi, pemeriksaan sejawat, kecukupan referensi, kajian kasus negatif dan pengecekan. Namun, dalam penelitian ini, tidak semua teknik 
di atas digunakan, hanya beberapa teknik yang tepat dan diperlukan saja yang digunakan. Untuk pengecekan keabsahan data menggunakan empat kriteria Moleong (2001), yaitu derajat kepercayaan (credibility), keteralihan (transferablity), kebergantungan (dependability) dan kepastian (confirmability).

\section{Teknik Analisis Data}

Analisis data merupakan proses mencari dan mengatur secara sistematis transkrip wawancara, cacatan lapangan, dan bahan-bahan lain yang telah dihimpun untuk menambah pemahaman menganai bahanbahan penelitian untuk memungkinkan mendapat temuan sebagai hasil penelitian (Bogdan 1990). Untuk memberikan pemaknaan atas data atau fenomena yang ditemukan dan dikumpulkan dalam penelitian ini, maka dilakukan analisis dengan pendekatan kualitatif dengan eksplanasi bersifat deskripsi. Dengan teknik analisis deskriptif, langkah yang ditempuh dalam analisis ini adalah mengorganisir data berupa gambar, foto, dokumen yang berupa laporan, biografi, artikel, buku-buku pedoman dan sebagainya (Moleong, 2001 : 103). Peneliti melakukan penarikan kesimpulan atau verifikasi, setelah terlebih dahulu melihat hubungan satu dengan yang lain dalam kesatuan bahasan. Selanjutnya peneliti melakukan interpretasi dan memberi makna terhadap fenomena yang ditemukan. Proses verifikasi ini ditempuh dengan tujuan untuk lebih memperkaya dan mengabsahkan hasil interpretasi yang dilakukan.

\section{Hasil Penelitian}

\section{Deskripsi tentang Desain Kurikulum yang Berorientasi PPL}

Ada enam (6) mata kuliah praktikum yang berorientasi pada pelaksanaan praktik profesi lapangan, yaitu : praktikum bahasa Arab, praktikum bahasa Inggris, praktikum ibadah, praktikum teknologi informasi, micro teaching, dan praktik profesi lapangan. Keenam mata kuliah tersebut merupakan mata kuliah khusus. Kekhusussannya terletak pada desain isinya yang berorientasi membekali mahasiswa (calon sarjana pendidikan Islam) agar mempunyai kemampuan dasar dan kemampuan mahir dalam mengajar. Di samping itu, ada dua puluh satu mata kuliah yang bisa membekali mahasiswa untuk mahir praktik mengajar dalam praktik profesi lapangan (PPL) karena isi maupun cakupannya memerlukan praktik sebagai latihan bagi mahasiswa. 313 
Kedua puluh satu mata kuliah tersebut bermuatan penguasaan bahaan utama mengajar ataupun praktikum mata kuliah. Artinya, mata kuliah itu disusun tidak semata-mata untuk praktik, tetapi di dalam isi mata kuliah itu memuat unsur untuk kerja praktik bagi mahasiswa. Misalnya mata kuliah bahasa, metodologi dan strategi pembelajaran, serta ilmuilmu keagamaan membutuhkan praktik baik dalam bentuk simulasi, demosntrasi, atau lainnya.

\section{Deskripsi tentang Pelaksanaan dan Evaluasi PPL}

Pelaksanaan pembelajaran untuk enam mata kuliah praktikum, ditawarkan secara berurutan dari semester pertama hingga semester delapan. Urutannya, semester ke-1 praktikum bahasa Arab, semester ke-2 praktikum bahasa Inggris, semester ke-3 praktikum ibadah, semester ke-4 praktikum teknologi informasi pendidikan, semester ke- 6 micro teaching, dan semester ke-7 praktik profesi lapangan. Sedangkan evaluasi pelaksanaan perkuliahan mata kuliah tersebut di Sekolah Tinggi Agama Islam Negeri Kudus mengacu pada tata pembelajaran dan evaluasi di STAIN Kudus. Evaluasi kelulusan tiap mata kuliah ditentukan minimal nilai 2.00, kecuali mata kuliah Praktik Profesi Lapangan (PPL) harus mencapai nilai minimal 3,49.

\section{Saran}

Pengelola perkuliahan PPL pada Jurusan Tarbiyah STAIN Kudus, serta para pengelola perguruan tinggi pada umumnya agar selalu konsisten mengembangkan kurikulum terutama yang berkaitan dengan peningkatan kemampuan mahasiswa untuk mahir mengajar.

\section{Penutup}

Demikian hasil penelitian ini, mudah-mudahan menjadi perhatian kajian bagi semua pihak, khususnya pengelola STAIN Kudus dan pendidikan tinggi. Penelitian dengn tema dan fokus yang serumpun teman ini lainnya diharapkan akan dilakukan untuk memperkaya pengembangan berikutnya. 


\section{DAFTAR PUSTAKA}

Buku Pedoman Akademik Sekolah Tinggi Agama Islam Negeri Kudus.

Bungin, Burhan. 2003. Analisis Data Penelitian Kualitatif: Pemahaman Filososfis dan Metodologis ke Arah Penguasaan Model Aplikasi. Jakarta:PT. RajaGrafindo Persada.

Matthew, Miles B, dan Huberman. 1992. Analisis Data Kualitatif. Terjemahan Tjetjep Rohendi. Jakarta: Universitas Indonesia.

McMillan, James H and Sally Schumacher. 2001. Research In Education A Conceptual Introduction. San Francisco: Longman.

Moleong, Lexy, J. 2000. Metodologi Penelitian Kualitatif. Yogyakarta: Rake Sarasin.

Nasution, S,. 1993. Pengembangan dan Inovasi Kurikulum. Jakarta: PT. Citra Aditya Bakti.

Nasution, S,. 1996. Metode Penelitian Naturalistik Kualitatif. Bandung: Tarsito. Soetopo, Henyat dan Soemanto, Wasty. 1986. Pembinaan dan Pengembangan Kurikulum. Jakarta: PT. Bima Aksara.

Subandijah. 1996. Pengembangan dan Inovasi Kurikulum. Jakarta: PT. Raja Grafindo Persada.

Sugiyono. 2008. Metode Penelitian Pendidikan Pendekatan Kuantitatif, Kualitatif dan $R \& D$. Bandung:Alfabeta.

UU RI No. 20 Tahun 2003 tentang Sistem Pendidikan Nasional

UU RI No. 12 Tahun 2012 tentang Pendidikan Tinggi 